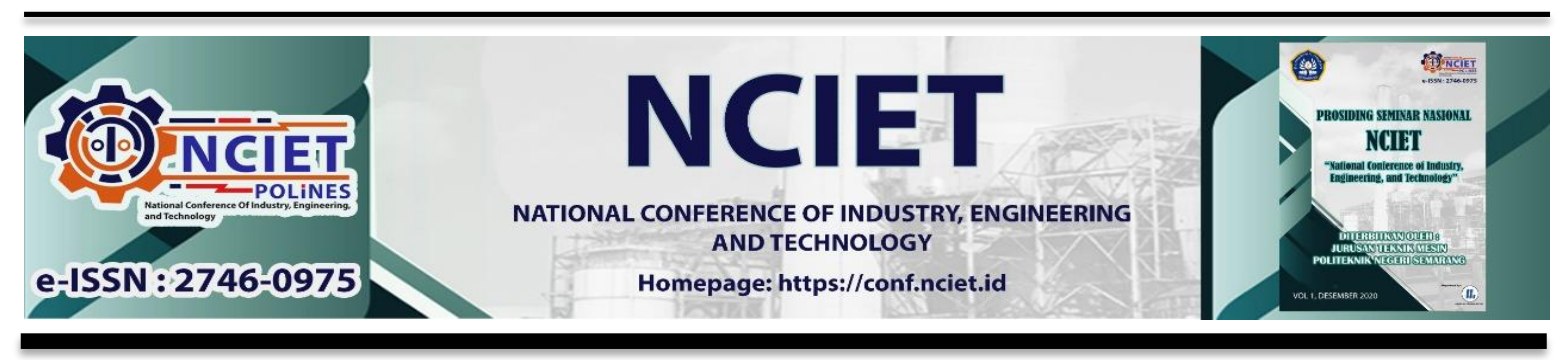

Prosiding Seminar Nasional NCIET Vol.1 (2020) B89-B98

$1^{\text {st }}$ National Conference of Industry, Engineering and Technology 2020,

Semarang, Indonesia.

\title{
STUDI VARIASI BENTUK SUDUT REFLEKTOR PADA BURNER KOMPOR BIOMASSA UB-03
}

\section{Nabila Maya Safitri, Saiful Anwar, Risse Entikaria Rachmanita, Bayu Rudiyanto*}

\author{
Jurusan Teknik, Politeknik Negeri Jember \\ Jl Mastrip, Kotak Pos 164, Jember, 68121 \\ *Email : bayu_rudianto@polije.ac.id
}

\begin{abstract}
Abstrak
Kompor biomassa merupakan salah satu media yang digunakan untuk melangsungkan reaksi pembakaran dengan bahan bakar biomassa, dan panas yang dihasilkan dimanfaatkan untuk keperluan memasak. Kompor biomassa yang digunakan oleh masyarakat umumnya masih sangat sederhana dengan efisiensi yang masih rendah. Maka upaya peningkatan efisiensi kompor terus dilakukan, baik secara rekayasa konstruksi maupun optimalisasi pemanfaatan api. Dalam penelitian ini dilakukan upaya peningkatan efisiensi dengan cara menambahkan reflektor pada kompor biomassa UB-03. Metode yang digunakan dalam pengujian ini adalah metode water boiling test. Beberapa parameter dalam pengujian kompor biomassa yaitu waktu start up, total waktu operasi, waktu pendidihan, kalor sensibel, kalor laten, energi kalor yang masuk (heat energy input) dan efisiensi termal. Hasil penelitian menunjukkan bahwa pada saat ditambahkan reflektor efisiensi kompor mengalami kenaikan 2,2-4,7\%. Kompor biomassa UB-03 memiliki efisiensi tertinggi pada saat ditambahakan reflektor $\angle 65^{\circ}$ dengan efisiensi sebesar $18,10 \%$ yaitu dengan bentuk seperti kerucut yang dipotong dengan diameter bawah lebih kecil daripada diameter atas. Selain itu reflektor juga berfungsi sebagai konsentrator api dan mempercepat waktu pendidihan air.
\end{abstract}

Kata kunci: Biomassa; Kompor Biomassa UB-03; Reflektor; Efisiensi

\section{PENDAHULUAN}

Indonesia merupakan negara kepulauan yang memiliki sumber daya alam melimpah yang dapat dimanfaatkan sebagai sumber energi untuk keberlangsungan hidup. Namun seiring berjalannya waktu, ketersediaan alam tersebut kini semakin menipis, dan untuk mengantisipasinya adalah dengan energi baru terbarukan (EBT) merupakan alternatif terbaik. Dimana energi terbarukan tidak berkontribusi terhadap perubahan iklim maupun pemanasan global. Energi terjadi karena proses alam yang berkelanjutan seperti angin, air, matahari, panas bumi maupun biomassa (KESDM, 2016).

Berdasarkan hasil persentase penggunaan bahan bakar utama rumah tangga menurut provinsi di Indonesia untuk memasak pada tahun 2016 oleh BPS (Badan Pusat Statistik) 
menyatakan bahwa penggunaan bahan bakar elpiji masih menempati persentase teratas yaitu sekitar $72,38 \%$. Sedangkan penggunaan kayu menempati posisi kedua dengan persentase 21,57\%.3,78\% menggunakan bahan bakar minyak tanah, 0,85\% menggunakan bahan bakar listrik, dan 1,24\% menggunakan bahan bakar lainnya (Badan Pusat Statistik, 2016).

Biomassa merupakan sumber energi terbarukan yang mengacu pada bahan biologis berasal dari organisme maupun tumbuhan dan dari hasil pengolahan. Limbah tanaman seperti sisa penebangan kayu sengon biasanya banyak dimanfaatkan untuk bahan bakar masyarakat pedesaan sehingga kapasitasnya yang mudah didapat serta tidak mengganggu ekosistem apabila digunakan.

Bahan bakar kayu untuk tungku mudah didapat dan murah terutama dikalangan masyarakat pedesaan Indonesia. Namun karena teknologi tungku yang dipakai sederhana, maka pencemaran udara karena asap dan gas-gas keluaran lainnya masih tinggi. Salah satu cara meminimalisir pencemaran ini adalah memodifikasi tungku bahan bakar kayu yang lebih efisien agar dapat memperoleh proses pembakaran yang sempurna. Kompor biomassa merupakan kompor yang sistem pembakarannya menggunakan bahan bakar biomassa untuk memproduksi kalor melalui pembakaran untuk penggunaan proses memasak domestik atau tujuan perancangan lain yang disesuaikan dengan kebutuhan pemakai (Nurhuda, 2015).

Meningkatkan efisiensi dari performa kompor biomassa dengan cara menambahkan reflektor pada kompor biomassa UB-03. Penambahan reflektor berpengaruh terhadap peningkatan efisiensi kompor biomassa UB-03 yaitu 1,39-6,34\% setelah ditambahkan dengan reflektor. Reflektor yang digunakan adalah dengan variasi sudut pada reflektor sehingga dapat menghasilkan reflektor yang mampu meningkatkan efisiensi maksimum (Ma'rifah, 2016). Peningkatan efisiensi terhadap diameter dan jumlah lubang juga mempengaruhi peningkatan efisiensi kinerja kompor UB-03 yaitu sebesar 1,04\%-10,02\%. Sehingga masukan udara yang terdapat pada reflektor mampu mensirkulasikan udara lebih baik untuk meningkatkan efisiensi kinerja kompor UB-03 (Wicaksono, 2017).

Penelitian ini bertujuan untuk meningkatkan efisiensi kinerja tungku dengan penambahan variasi sudut reflektor yaitu dengan variasi $\angle 55^{\circ}, \angle 60^{\circ}, \angle 65^{\circ}$ dan dilakukan penambahan lubang sebanyak 10 buah pada reflektor. Sehingga reflektor pada kompor berfungsi untuk mendistribusikan udara pembakaran ke dalam burner atau ruang pembakar, guna untuk memperoleh hasil pembakaran yang sempurna. Selain itu reflektor diharapkan memiliki keluaran untuk menangkap losses radiasi dari api ke sekeliling dan merefleksikan 
kembali ke area beban serta memfokuskan arah api, sehingga dapat meminimalisir panas yang terbuang dan akan mampu meningkatkan efisiensi dari kompor tersebut.

Metode untuk pengujian efisiensi thermal tungku menggunakan metode WBT dengan alasan mempermudah penerapan saat analisa di lapangan. Metode ini menggunakan fase high power, cold start yang artinya pengujian dilakukan dari suhu air masih dalam keadaan dingin hingga mencapai suhu didih (Taufan, 2013).

\section{METODE PENELITIAN}

Penelitian ini dilaksanakan di Workshop dan Laboratorium Teknik Energi Terbarukan, Politeknik Negeri Jember, Kabupaten Jember, Jawa Timur. Tahapan kegiatan dalam penelitian dimulai dari studi literature, Perancangan Reflektor, Persiapan alat dan bahan, pengujian penggunaan kompor dengan penambahan refelktor dan tanpa reflektor, perhitungan efisiensi, pembahasan dan kesimpulan.

Peralatan yang digunakan dalam penelitian ini yaitu termokopel, gunting besi, stopwatch, Dekko FR-7822 infrared thermometer, neraca, wadah (ember), panci. Sedangkan bahan yang digunakan adalah kayu sengon sebagai bahan bakar, dan plat stainless steel sebagai bahan pembuatan reflektor

\section{Desain dan Skematik Pengujian}

Peranncangan alat yang dilakukan dalam penelitian dimulai dengan pembuatan desain alat yang akan dibuat, kemudian menentukan dimensi dari setiap ukuran. Reflektor yang dibuat ada 3 macam bentuk sudut yang berbeda yaitu dengan variasi sudut $\angle 55^{\circ}$ (ukuran diameter atas $12,8 \mathrm{~cm}$, bawah $8 \mathrm{~cm}$ dan tinggi $4 \mathrm{~cm}$ ), reflektor dengan sudut $\angle 60^{\circ}$ (ukuran diameter atas $11,4 \mathrm{~cm}$, bawah $8 \mathrm{~cm}$ dan tinggi $4 \mathrm{~cm}$ ), dan reflektor dengan sudut $\angle 65^{\circ}$ (ukuran diameter atas 10,8 cm, bawah $8 \mathrm{~cm}$ dan tinggi $4 \mathrm{~cm}$ ). Dengan harapan dapat bentuk reflektor yang dapat meningkatkan efisiensi tertinggi.

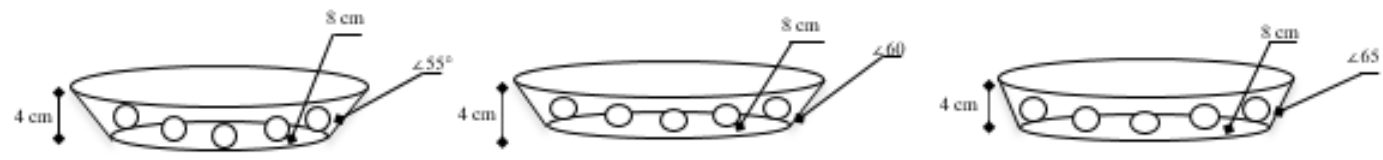

Gambar 1. Perancangan reflektor sudut $\angle 55^{\circ}, \angle 60^{\circ}, \angle 65^{\circ}$.

Pengujian dan pengambilan data dilakukan dengan penambahan reflektor dan tanpa reflektor. Pengujian ini bertujuan untuk mengetahui pengaruh penambahan reflektor dengan 
bentuk sudut yang berbeda terdadap efisiensi kompor biomassa UB-03. Dilakukan pengujian tanpa isiensi reflektor untuk membandingkan efisiensi yang dihasilkan. Berikut merupakan skematik pengujian.

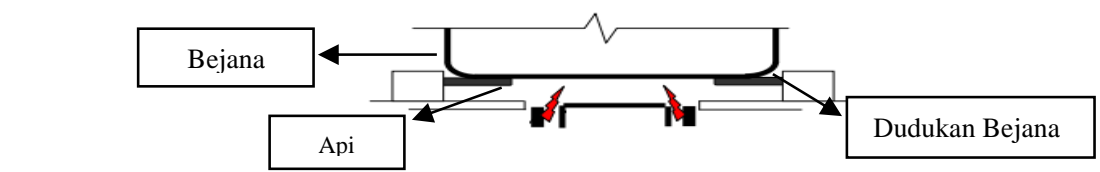

Gambar 2. Sistematika Tanpa Reflektor

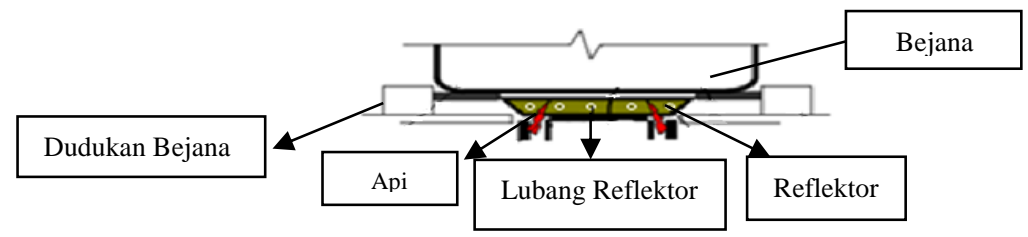

Gambar 3. Sistematika Tanpa Reflektor

\section{Pengujian Kompor Biomassa}

Pengujian twrdiri dari pengujian performa tungku menggunakan metode Water Boiling Test (WBT). Metode WBT digunakan dengan alasan kemjudahan penerapan dilapangan untuk mendapatkankarakter dari tungku yaitu berupa efisiensi termal. Proses pengukuran suhu pada tiap parameter dimulai ketika api sudah mulai stabil dan panci diletakkan diatas tungku.Input energi yang diperhitungkan adalah semua energi langsung yang digunakan dalam proses pemanasan. Energi langsung berupa energi bahan bakar berupa kayu bakar. Berikut merupakan peletakan pengukuran tiap titik temperatur

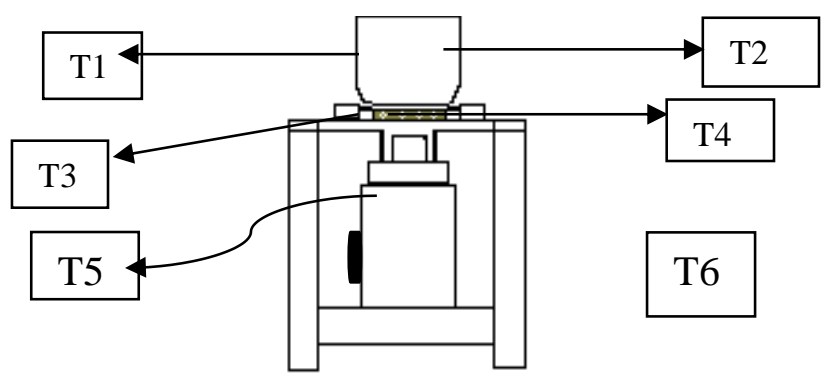

Gambar 4. Peletakan Pengukuran Tiap Titik Temperatur

$\mathrm{T} 1=$ Temperatur air, $\mathrm{T} 2=$ temperatur bejana, $\mathrm{T} 3=$ temperatur api, $\mathrm{T} 4=$ temperatur reflektor, T5 = temperatur dinding kompor, T6 = temperatur lingkungan.

Data yang akan diambil pada penelitian ini diantaranya $\mathrm{T}_{\text {air awal }}, \mathrm{T}_{\text {air akhir }}, \mathrm{T}_{\text {panci }}, \mathrm{T}_{\text {dinding kompor }}$, $\mathrm{T}_{\text {bara api }}, \mathrm{T}_{\text {reflektor }}, \mathrm{T}_{\text {ling }}, \mathrm{t}_{\text {penyalaan, }}, \mathrm{t}_{\text {mendidihkan }}$ dan $\mathrm{t}_{\text {total }}$ untuk mengetahui panas . Perhitungan Efisiensi termal adalah rasio energi yang digunakan dalam pendidihan dan dalam penguapan air terhadap energi panas yang tersedia dalam bahan bakar. Efisiensi termal dihitung dengan rumus: 


$$
\eta=\frac{m \cdot C p \cdot \Delta T+\Delta m_{a} h f g}{m_{k} \times L H V} \times 100
$$

Dimana:

$\begin{array}{ll}\mathrm{m} & =\text { Massa air }(\mathrm{kg}) \\ \mathrm{Cp} & =\text { Panas jenis air }\left(\mathrm{kJ} / \mathrm{kg}^{\circ} \mathrm{C}\right) \\ \Delta T & =\text { Beda suhu air }\left({ }^{\circ} \mathrm{C}\right) \\ m_{a} & =\text { Massa air }(\mathrm{kg}) \\ h_{f g} & =\text { Panas laten penguapan }(\mathrm{kJ} / \mathrm{kg}) \\ m_{k} & =\text { Massa bahan bakar }(\mathrm{kg}) \\ \mathrm{LHV} & =\text { Nilai kalor rendah bahan bakar }(\mathrm{kJ} / \mathrm{kg})\end{array}$

\section{HASIL DAN PEMBAHASAN}

\section{Hasil Data yang Diperoleh Selama Pengujian Kompor Biomassa UB-03 Tanpa Penambahan Reflektor.}

\begin{tabular}{lll}
\multicolumn{2}{l}{ Tabel 1. Data Hasil Pengujian Kompor Biomassa Tanpa Penambahan Reflektor } \\
\hline No & Keterangan & Kompor Biomassa UB-03 \\
\hline 1 & Massa air $(\mathrm{gr})$ & 2.365 \\
2 & Massa uap (gr) & 25,12 \\
3 & Massa bahan bakar terpakai $(\mathrm{gr})$ & 165 \\
4 & Lama pemasakan air (menit) & 18 \\
5 & LHV $(\mathrm{kJ} / \mathrm{kg})$ & 16823,4 \\
6 & $\mathrm{Q}_{\text {in }}(\mathrm{kJ})$ & 5728.368 \\
7 & $\mathrm{Q}_{\text {sensibel }}(\mathrm{kJ})$ & 727,0956 \\
8 & $\mathrm{Q}_{\text {laten }}(\mathrm{kJ})$ & 22,595 \\
9 & Efisiensi termal $(\%)$ & $13 \%$ \\
\hline
\end{tabular}

Dari data hasil pengujian pada tebel 4.1 menyatakan bahwa kompor biomassa UB-03 untuk mendidihkan air 2,4 liter pada ulangan pertama membutuhkan waktu 18 menit, energi bahan bakar yang digunakan yaitu sebesar 5049,824 kJ yang diperoleh dari 3400 gram kayu dengan nilai kalor 16823,4 kJ sehingga memperoleh efisiensi sebesar $13 \%$.

Unjuk kerja kompor biomassa UB-03 dengan Penambahan Reflektor dengan sudut $\angle 55^{\circ}, \angle 60^{\circ}$, dan $\angle 65^{\circ}$. 
Tabel 2. Data Hasil Pengujian Kompor dengan Penambahan Reflektor Variasi Sudut $\angle 55^{\circ}$,

\begin{tabular}{|c|c|c|c|c|}
\hline No & Keterangan & Reflektor $55^{\circ}$ & Reflektor $60^{\circ}$ & Reflektor $65^{\circ}$ \\
\hline 1 & Massa air (gr) & 2.370 & 2.216 & 2.311 \\
\hline 2 & Massa uap (gr) & 21,66 & 53,33 & 45 \\
\hline 3 & $\begin{array}{l}\text { Massa bahan bakar } \\
\text { terpakai (gr) }\end{array}$ & 266,83 & 256,66 & 265,33 \\
\hline 5 & $\begin{array}{l}\text { Lama pemasakan } \\
\text { air (menit) }\end{array}$ & 15 & 15 & 15 \\
\hline 6 & $Q_{\text {in }}(\mathrm{kJ})$ & 5052,628 & 5049,824 & 5047,02 \\
\hline 7 & $\mathrm{Q}_{\text {sensibel }}(\mathrm{kJ})$ & 742,2786 & 693,9065 & 813,2719 \\
\hline 8 & $\mathrm{Q}_{\text {laten }}(\mathrm{kJ})$ & 48,92043 & 120,4965 & 100,543 \\
\hline 9 & Efisiensi termal (\%) & $15,66775 \%$ & $16,11811 \%$ & $18,1603 \%$ \\
\hline
\end{tabular}

Kompor biomassa memiliki prinsip kerja di mana bahan bakar yang terbakar didalam ruang pembakaran karena adanya kontak bahan bakar dengan udara, kemudian panas yang dihasilkan dari proses pembakaran tersebut dimanfaatkan untuk keperluan sehari-hari. Dari data hasil pengujian, penambahan reflektor dengan tiga variasi sudut yaitu $\angle 55^{\circ}, \angle 60^{\circ}$, dan $\angle 65^{\circ}$, dengan jumlah lubang masukan udara sebanyak 10 buah dengan diameter lubang masing-masing $1 \mathrm{~cm}$. Penambahan reflektor dengan sudut $\angle 55^{\circ}$ membutuhkan waktu ratarata 15 menit, membutuhkan energy bahan bakar sebesar 5052,628 kJ sehingga menghasilkan efisiensi sebesar 15,66\%. Penambahan reflektor dengan sudut $\angle 60^{\circ}$ membutuhkan waktu rata-rata 15 menit untuk mendidihkan air dan membutuhkan energi bahan bakar sebesar 5049,824 kJ sehingga menghasilkan efisiensi sebesar 16,11\%. Sedangkan pada penambahan reflektor dengan sudut $\angle 65^{\circ}$ mengalami penurunan efisiensi yaitu 18,16\% dengan kebutuhan energy 5047,02 kJ. Semakin tinggi kebutuhan energy bahan bakar maka semakin kecil nilai efisiensi yang diperoleh.

Pada penambahan reflektor juga dipengaruhi oleh jumlah dan ukuran lubang yang terdapat pada reflektor. Di mana lubang pada reflektor berpengaruh terhadap udara yang masuk pada saat berlangsungnya proses pembakaran. Semakin kecil diameter lubang maka semakin sedikit pula masukan udara, semakin besar diameter udara maka semakin banyak pula masukan udara untuk berlangsungnya proses pembakaran pada kompor biomassa UB03. Penambahan 10 lubang dapat mengoptimalkan menangkap panas radiasi dan mampu merefleksikan ke area beban dengan baik sehingga panas yang tadinya hilang akan berguna untuk memanaskan beban (Fariz Wicaksono, 2017). Berdasarkan hasil pengujian tersebut terlihat bahwa penambahan reflektor dapat mempengaruhi efisiensi kompor biomassa UB- 
03. Terdapat beberapa faktor yang mempengaruhi terjadinya kenaikan maupun penurunan suhu terhadap penambahan reflektor. Ketika proses pemasakan air , sebagian kalor yang dihasilkan untuk pemasakan air di mana kalor akan diserap oleh air, sedangkan sebagian kalor yang dihasilkan akan mengalir ke lingkungan. Kalor yang mengalir ke lingkungan disebabkan oleh luas kontak dan nyala api. Luas kontak antara nyala api dengan permukaan panci cenderung bertambah seiring bertambahnya waktu, namun luas kontak antara nyala api dengan permukaan panci juga dapat memperbesar pengaruh aliran kalor ke lingkungan.

\section{Perbandingan Efisiensi Kompor dengan Penambahan Reflektor dengan Variasi Sudut} $\angle 55^{\circ}, \angle 60^{\circ}, \angle 65^{\circ}$ dan Tanpa Reflektor.

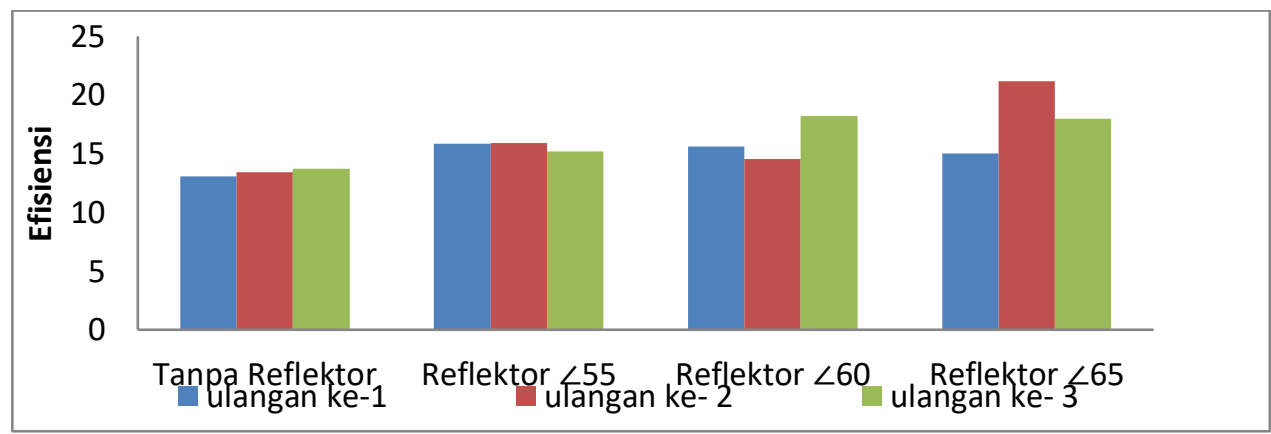

Gambar 5. Grafik Efisiensi Kompor dengan Penambahan Reflektor $\angle 55^{\circ}, \angle 60^{\circ}, \angle 65^{\circ}$ dan Tanpa Reflektor.

Dari hasil data yang diperoleh menunjukkan bahwa kompor biomassa mengalami peningkatan efisiensi setelah ditambahkan dengan reflektor. Namun bentuk terhadap reflektor juga mempunyai hasil efisiensi yang berbeda pula. Hal tersebut dipengaruhi oleh udara yang masuk selama proses pembakaran, sehingga udara yang digunakan sesuai dengan kebutuhan pada proses pembakaran. Adapun faktor yang mempengaruhi nilai efisiensi adalah pada saat penambahan reflektor, panas yang dihasilkan oleh proses pembakaran dapat direfleksikan sehingga panas yang seharusnya terbuang ke lingkungan dapat digunakan untuk membantu proses pemasakan. Efisiensi termal merupakan rasio energi yang digunakan dalam pendidihan dan penguapan air terhadap energi panas yang tersedia dalam bahan bakar. Berdasarkan gambar 4.22 dapat diketahui bahwa efisiensi kompor sebelum ditambahkan reflektor dari 3 pengulangan yaitu 13,08\%, 13,4\%, dan 13,72\%. Setelah ditambahkan reflektor efisiensi mengalami peningkatan. Efisiensi ketika ditambahkan reflektor dengan variasi sudut $\angle 55^{\circ}$ dari ke-3 ulangan yaitu $15,85 \%, 15,93 \%$, dan $15,21 \%$. Pada saat ditambahkan reflektor dengan sudut $\angle 60^{\circ}$ meningkatkan efisiensi yaitu $15.6 \%$, 
$14.57 \%$, dan 18,24\% dari masing-masing ulangan. Pada saat ditambahkan reflektor dengan sudut $\angle 65^{\circ}$ dapat meningkatkan efisiensi dengan tiga ulangan masing-masing yaitu $15 \%$, $21,71 \%$ dan $18 \%$. Dengan demikian efisiensi terbesar adalah ketika penambahan reflektor dengan variasi sudut $\angle 65^{\circ}$. hal ini disebabkan karena reflektor dengan sudut $\angle 65^{\circ}$ saat berlangsungnya pembaran dapat secara optimal menangkap dan merefleksikan panas ke area beban dengan baik sehingga panas yang seharusnya terbuang ke lingkungan dapat dimanfaatkan kembali untuk membantu proses pemasakan.

Penambahan reflektor dengan sudut $\angle 55^{\circ}$ dan $\angle 60^{\circ}$ menghasilkan efisiensi yang lebih rendah dibandingkan pada saat penambahan reflektor dengan sudut $\angle 65^{\circ}$. Hal ini menyatakan bahwa reflektor $\angle 55^{\circ}$ dan $\angle 60^{\circ}$ menyerap panas lebih rendah sehingga meskipun merefleksikan panas ke arah beban, namun tidak memberikan kontribusi panas yang lebih. Dari hasil penambahan reflektor terhadap kompor biomassa UB-03 tersebut mampu meningkatkan efisiensi kompor dibandingkan pada saat tidak ditambahkan reflektor. Terjadinya peningkatan efisiensi tersebut dikarenakan losses panas radiasi dari api hasil pembakaran ditangkap dan direfleksikan kembali ke area api sehingga radiasi api tersebut akan meneruskan ke beban, sehingga beban lebih lama berkontak dengan panas.

\section{KESIMPULAN}

Setelah dilakukan penelitian, dapat disimpulkan bahwa:

Penambahan reflektor berpengaruh terhadap peningkatan efisiensi kompor biomassa UB-03-1. Efisiensi kompor mengalami peningkatan 2,2\%-4,7\% setelah ditambahkan dengan reflektor. Selain berpengaruh terhadap peningkatan efisiensi, reflektor juga berfungsi sebagai konsentrator pada api dan lebih cepat waktu yang dibutuhkan untuk pendidihan air. Efisiensi kompor biomassa UB-03 sebelum ditambahkan dengan reflektor efisiensinya sebesar $13,4 \%$, namun setelah ditambahkan dengan reflektor efisiensinya terus meningkat menjadi $15,6 \%$ pada saat ditambahkan reflektor dengan sudut $\angle 55^{\circ}$, ketika ditambahkan reflektor dengan sudut $\angle 60^{\circ}$ menjadi $16,12 \%$ dan $18,10 \%$ setelah ditambahkan dengan reflektor bersudut $\angle 65^{\circ}$. Reflektor dapat mempengaruhi efisiensi, bentuk dari reflektor juga dapat mempengaruhi terhadap peningkatan efisiensi pada kompor dengan kontribusi yang berbeda. Selain berpengaruh terhadap peningkatan efisiensi, reflektor juga berfungsi sebagai konsentrator pada api dan lebih cepat waktu yang dibutuhkan untuk pendidihan air.Perancangan variasi sudut reflektor yang memiliki efisiensi terbesar dengan range $\angle 65^{\circ}$ sampai dengan $\angle 90^{\circ}$. 


\section{DAFTAR PUSTAKA}

Afandi., Salimin., Delly J., 2018. Pengaruh Pemanfaatan Faba (Fly Ash and Bottom Ash) Terhadap Panas Pada Tungku Arang. Enthalpy. Vol. 3. No. 1. e-ISSN: 2502-8944.

Andi T., Novrinaldi., Umi., 2013. Rancang Bangun dan Pengujian Tungku

Berbahan Bakarn Gas untuk Industri Tahu Tradisional Berbasis Produksi Bersih. Agritec. Vol. 33. No. 4.

Ardiansyah, T. 2016. Perancangan Tungku Industri Gula Merah Berbahan Batu Padas. Skripsi. Jurusan Teknik: Politeknik Negeri Jember

Arif M., Mirmanto., Muhammad A., 2016. Pengaruh Ketinggian Lubang Udara Pada Tungku Pembakaran Biomassa Terhadap Unjuk Kerjanya. Dinamika Teknik Mesin. Vol. 6. No. 1.

Aulia, Y. 2010. Rancang Bangun Dan Uji Teknis Kompor Briket Dengan

Menggunakan Bahan Bakar Briket Kulit Kakao. Sikripsi. Fakultas Teknik Pertanian: Universitas Andalas Padang.

Padat Skala Industri Rumah Tangga. Prosiding Seminar Nasional Kimia.

Wicaksono, F. 2017. Pengaruh Penggunaan Reflektor dengan Penambahan Jumlah Lubang Terhadap Efisiensi pada Kompor Biomassa UB-03-1. Skripsi. Jurusan Teknik. Politeknik Negeri Jember.

Maulidin I., Ikhsan M., Juarsa R.P., Qadafi A.M., Komala W., 2018. Inovasi Media Pembelajaran Alternatif Berbasis Pendidikan Lingkungan dengan Metode Kasmaran. Indonesian Journal of Educational Studies Vol.21, No.1. E-ISSN: 2621-6744,. P-ISSN: 2621-6736.

Ma'arifah.2016. Optimalisasi Pemanfaatan Api dengan Penambahan Reflektor Terhadap Efisiensi Kompor Biomassa UB-03. Skripsi. Jurusan Teknik. Politeknik Negeri Jember.

Ndraha, N. 2009. Uji Komposisi Bahan Pembuat Briket Bioarang Tempurung Kelapa Dan Serbuk Kayu Terhadap Mutu Yang Dihasilkan. Skripsi. Departemen Teknologi Pertanian. Sikripsi. Fakultas Pertanian: Universitas Sumatera Utara.

Nurhuda, M. 2015. Spesifikasi Kompor Biomassa UB Standar Bahan Bakar Potongan Kay. CV. Kreasi Daya Mandiri. Malang.

Papilo P., Kunaifi., Hambali E., Nurmiati., Pari R.F., 2015. Penilaian Potensi Biomassa sebagai Alternatif Energi Kelistrikan. Jurnal Pasti. Vol. IX. No. 2, hal164-176.

Qanitah. 2014. Evaluasi Kinerja Tungku Berbahan Bakar Kayu Dengan Variasi Luas Pintu Udara Masuk. Skripsi. Jurusan Teknik: Politeknik Negeri Jember.

Selilana E.A., Suwandi., Ayodha T., 2017. Pengaruh Tinggi dan Jumlah Lubang Udara pada Tungku Pembakaran serta Variasi Kecepatan Aliran Udara Terhadap Kinerja Kompor Gasifikasi Biomassa. e-Proceeding of Enginering. Vol. 4. No. 3. ISSN:23559365. Hal. 3862.

Subekti, P. 2012. Perhitungan Komperasi Energi Bahan Bakar Sekam Padi dengan Minyak Tanah. Jurnal APTEK. Vol. 4. Hal. 41-48

Sudarno dan Fadelan. 2015. Peningkatan Efisiensi Kompor LPG dengan menggunakan Reflektor Radiasi Panas Bersirip. Jurnal Ilmiah Semesta Teknik. Vol.18. No.1. Hal. 94105.

Sudarno., Soeparman S., Wahyudi S., Widodo A.S. 2018. Unjuk Kerja Reflektor Radiasi Panas dengan 1 Baris Sirip Terhadap Efisiensi Kompor LPG. Jurnal Rekayasa Mesin. Vol. 9. No. 2. ISSN:0216-468X. Hal 75-84.

Syamsiro M., 2016. Peningkatan Kualitas Bahan Bakar Padat Biomassa Dengan Proses Densifikasi Dan Torrefaksi. Jurnal Mekanika dan Sistem Termal (JMST). Vol. 1. No. 1. 
Yunianto B., Nazarudin S., Ramanda S.A.K., 2014. Pengembangan Desain Tungku Bahan Bakar Kayu Rendah Polusi Dengan Menggunakan Beton Semen. Jurnal Teknik Mesin. Vol. 16. No. 1Vol. 16, No. 1.

Yuswansyah, Y.E. 2013. Potensi Penerimaan Masyarakat Terhadap Kompor Biomassa UB-03. Sikripsi. Jurnal Teknik Pertanian Lampung: Universitas Lampung. Vol. 2. No. 1. Hal. 77-84.

Sawir, H. 2016. Kompor Biomassa (Sebagai Upaya Pemanfaatan Limbah Menjadi Energi). Formulir Aplikasi Penghargaan Inovasi K3 dan Lingkungan Hidup PT Semen Padang. 